\title{
"Criminality" and the Right to Treatment
}

\author{
Grant H. Morris†
}

When science superseded superstition, society surrendered its supposition that the madman was a badman. The madman was not wicked, he was merely sick. He suffered not from demons, but from mental illness. While society adopted this medical conceptualization to explain certain abnormal behavior, it did not adopt that model to explain all deviate behavior. Certain abnormal behavior is also anti-social. Criminals engage in anti-social conduct. Criminals are evil. Their activity could not, or would not, be explained by medicine.

As a consequence, society embarked on a great segregation program. The mentally ill-sick people-were segregated from the criminalswicked people. The mentally ill were confined in asylums, later called mental hospitals, for the purpose of treatment. The criminals were confined in prisons for the purpose of punishment. In essence, the mental institution took its first step toward achieving respectability and acceptability in the community through the systematic exorcism of these evil spirits, i.e., criminals, from its confines.

To be sure, the early treatment methods were barbaric and the mentally ill often suffered as much as the prisoners who were being punished, ${ }^{1}$ but the suffering of the mentally ill was under the guise of treatment. One notable example of this treatment-in the twentieth century holes were not drilled into the skulls of the mentally ill to permit evil spirits to escape, but lobotomies, a surgical severing of nerve fibers in the brain, were performed as a form of treatment to make patients more manageable. ${ }^{2}$

The most significant advancement in the treatment of the mentally ill has resulted from the introduction of tranquilizing and other psycho-active drugs in the mid-1950's. These drugs do not, in and of themselves, cure patients. But they do make patients more amenable to

$\dagger$ Associate Professor of Law, Wayne State University. This article was presented, in part, at a Wayne State University Law School Symposium on The Mentally Ill and the Right to Treatment, April 18, 1969.

1 A. Deutsch, The Mentally Ill In America 77-83 (2d ed. 1949).

2 A. Noyes \& L. Kolb, Modern Clinical Psychiatry 614-2I (5th ed. 1958); 3 Lawyers' Medical Cyclopedia 42-44 (C. Frankel, J. Holloway, P. McMaster \& K. Reddon eds. 1958). 
other forms of psychiatric treatment by relieving the symptoms of mental illness. ${ }^{3}$ With increased usage of tranquilizing drugs, restraint and seclusion rates in the mental hospitals plummeted. However, hospital administrators discovered that although patients had become quieter with tranquilizers and responded more readily to other forms of therapy, in the close confines of locked door wards, patients were still restless and tense. ${ }^{4}$ To alleviate this condition, hospitals experimented with "open-door" policies. In those institutions where the open-door policy was given a genuine trial, it proved to be an effective aid to therapy. ${ }^{5}$ Patient tension was reduced, patient receptivity to treatment was increased, and patient dignity was restored. Restraint and seclusion rates decreased substantially. The great fears surrounding the open-door concept did not materialize. Patients did not elope (i.e., escape) more frequently than before the wards were opened. ${ }^{6}$ Patients did not injure other patients more frequently than before the wards were opened. ${ }^{7}$

The open door has not only proved itself an effective aid to therapy, it has become an essential part of therapy. The drugs and the open door have signaled the end of the mental hospital as a predominantly custodial institution. The mental hospital has acquired a new image and has achieved increased respectability.

New terminology has asserted itself to explain new treatment techniques. "Therapeutic community," "patient government," "voluntary patients," "out-patient clinics," "comprehensive community mental health centers," "continuum of services" are phrases that have only recently acquired palpable meaning. The mental hospital itself is now viewed as only one part of the total treatment picture. For the first time, the treatment accorded the mentally ill can be clearly differentiated from the punishment accorded criminals.

With this basic explanation of the recent advancements in treatment of the mentally ill, let me return to the distinction made by society between the mentally ill and the criminal. It is not my purpose to

3 U.S. Dep't of Health, Education, and Welfare, MEntal Illness aNd Its TreatMent 14 (1965); U.S. Dep'T of Health, Education, and Welfare, The Comprehensive ComMUNity Mental Health Center 6-7 (1964).

4 Snow, Open Ward Policy at St. Lawrence State Hospital, 115 AM. J. PsychuArry 779, 781 (1959).

5 See Hurst, The Unlocking of Wards in Mental Hospitals, 114 AM. J. Psychiatry 306 (1957); Koltes, Mental Hospitals with Open Doors, 113 AM. J. Psychiatry 250 (1956); Snow, supra note 4. It should be noted that the "open-door" policy is not a recent innovation. See generally 43 AM. J. INSANITY 181-203 (1886) for a discussion of the policy as utilized by progressive hospitals of the nineteenth century.

6 Hurst, supra note 5, at 307; Snow, supra note 4, at 780.

7 Snow, supra note 4 , at 780 . 
reexamine and redefine the overworked ${ }^{8}$ standard of criminal responsibility. It is not my purpose to suggest that all criminals really suffer from mental illness and that the medical model should be expanded to explain all anti-social behavior. The desirability of using a therapeutic approach to achieve personality reformation in criminals has recently been analyzed and advocated by Dr. Karl Menninger. ${ }^{9}$ Nor do I intend to explore the somewhat opposing view of Dr. Thomas Szasz, ${ }^{10}$ who suggests that society has succumbed to the propaganda of mental health enthusiasts and that to accept the concept of mental illness as a medically treatable disease is unfounded. Perhaps my comments may add new perspective to those opinions and may suggest reevaluation of the strengths of those arguments.

What I propose to do is focus attention on a more practical problem: What is the extent of the right to treatment of those persons that society has labelled as both mentally ill and "criminal"? It is my belief that in the movement to dissociate mentally ill persons from criminals, the pendulum has swung too far. Obviously, a mentally ill person should not be treated as a criminal solely because he was diagnosed as mentally ill; but can it be argued in this context, that a mentally ill criminal should not be treated as a mentally ill person? It is my contention that if society can legitimately determine that certain people can be involuntarily treated for mental illness, all persons so classified are entitled to equal treatment regardless of any other status such as "criminal" that has been attached to them. To the principle of a right to treatment must be added a corollary. In the attempt to increase the level of treatment for all mental patients, the level of treatment of any artificially disadvantaged class of patients must be raised to the level of all other patients. The norm must be sought for all abnormal.

\footnotetext{
8 Recently, Norval Morris has written, "Rivers of ink, mountains of printer's lead, forests of paper have been expended on this issue, which is surely marginal to the chaotic problem of effective, rational, and humane prevention and treatment of crime." $N$. Morris, Psychiatry and the Dangerous Criminal, 41 S. CAL. L. REv. 514, 516 (1968).

$9 \mathrm{~K}$. Menninger, The Crnme of Punishment 254, 257 (1968). Though Dr. Menninger advocates the "treatment" of crime as if it is an "illness," he distinguishes between "illness" and "disease." "Diseases are undesired states of being which have been described and defined by doctors, usually given Greek or Latin appellations, and treated by long-established physical and pharmacological formulae. Illness, on the other hand, is best defined as a state of functioning of such a nature that the public expects the sufferer to repair to the physician for help. The illness may prove to be a disease; more often it is only vague and nameless misery, but something which doctors, not lawyers, teachers, or preachers, are supposed to be able and willing to help." Id. at 254.

10 See generally T. SzASz, LAw, L.rBeRTY, AND Psychiatry (1963); T. SzASz, The MYth of MENTAL ILINESS (1961).
} 
But who are the mentally ill criminals? If a person who has been convicted of a crime and sentenced to prison develops mental illness while serving that sentence, he can be accurately labelled a mentally ill criminal. Shortly after conviction, the criminal may suffer remorse concerning the heinous crime he has committed. At the other end of the spectrum, a convict may become depressed over the length of the sentence imposed on him and/or the amount of time he has already served in prison. From these or other sources a mental condition may develop which requires psychiatric treatment.

There are other mentally ill persons who are "treated" as if they are mentally ill convicts though they have not been convicted of crimes. It is an elementary but fundamental principle of our legal system that a person accused of a crime is presumed innocent until he is proven guilty.11 Although he may be required to post bail and is obligated to appear at his trial, he does not forfeit his right to vote, to engage in a profession, or other civil rights ${ }^{12}$ by his status as an accused. Nevertheless, in many states, a defendant in a criminal case who is determined to be mentally incompetent to stand trial is handled as a mentally ill convict. Through his mental condition, he is embraced by the mantle of criminality. Similarly, society has "twice-cursed" persons found not guilty of crimes by reason of insanity. ${ }^{13}$ In some jurisdictions, sexual psychopath legislation has been enacted, and confinement in this category is not necessarily dependent upon conviction of a criminal offense. ${ }^{14}$ There are other categories and sub-categories, classifications and sub-classifications, labels and sub-labels which vary from state to state and range from dangerous mentally ill civil patients $^{15}$ to defective delinquents ${ }^{16}$ to mentally disordered sex offenders. ${ }^{17}$ The generic term that most appropriately describes these un-

11 See, e.g., Whitree v. State, 56 Misc. 2d 693, 703-4, 290 N.Y.S.2d 486, 498 (Ct. Cl. 1968).

12 See generally S. RUBIN, The LAw of Criminal Correction $611-44$ (1963), for a discussion of civil rights lost upon conviction of crime.

13 For example, by statute in Colorado, persons who are charged with certain crimes and who are mentally incompetent to stand trial, as well as persons acquitted of those crimes by reason of insanity, are labelled as "criminal insane" and confined in the same ward as mentally ill, sentence-serving convicts. Colo. REv. STAT. ANN. § 71-2-2 (1963). See note 17 infra for the text of this statute.

14 See, e.g., CaL. WELF. \& INST. CoDE §§ 6450-67 (Deering Supp. 1968) (mentally abnormal sex offenders); D.C. CODE ANN. $\$ \$ 22-3503$ to -3511 (1967) (sexual psychopaths); Il. ANN. STAT. ch. 38, \$§ 105-1.01 to -12 (Supp. 1969) (sexually dangerous persons); Mass. ANn. LAws ch. 123A, §§ 1-9 (1965, Supp. 1968) (sexually dangerous persons).

15 N.Y. MENT. Hyg. LAW \$ 85 (McKinney Supp. 1968).

16 Md. Code ANN. art. 31B, $\$$ 5-11A (1957, Supp. 1968); MAss. ANN. Laws ch. 123, $\S \S 113-24$ (1965); N.Y. CoRrec. LAW $\S \S 450-1$ (McKinney 1968).

17 Cal. Welf. \& INST. CODE $\$ \S 6300-80$ (Deering Supp. 1968). The Colorado statute is an outstanding example of vague but all-inclusive categorization. CoLo. REv. STAT. ANN. \$ 71-2-2 (1963) provides: 
fortunates is "mentally ill, non-criminal criminals" and I prefer to use this term. ${ }^{18}$

How does the treatment accorded mentally ill criminals and mentally ill non-criminal criminals differ from that accorded other mental patients, and is it inferior? In 1964, Dr. Charles E. Smith, Medical Director of the United States Bureau of Prisons, reported ${ }^{19}$ that there were only 56 psychiatrists employed full time in the approximately 230 adult correctional institutions in the United States. Eighteen of the 56 were working in federal prisons, leaving only 38 full-time psychiatrists in the state institutions. That's less than four-fifths of one full-time psychiatrist per state! With the monetary pressures of the Vietnam War and the urban crisis, it is doubtful that sufficient funds have been allocated since 1964 or will be allocated in the near future to lure a significant number of psychiatrists to this type of practice.

Someone may wish to argue that in my discussion of mental treatment in prisons I must be talking only of diagnosis and treatment of mentally ill sentence-serving convicts and not non-criminal criminals. That argument is not entirely valid. Some mentally ill non-criminal criminals are confined within prisons. For example, the state of New Hampshire judicially adopted ${ }^{20}$ a forward looking product-of-mentaldisease test of criminal responsibility in 1871 - over eighty years prior to the Durham decision ${ }^{21}$ in the District of Columbia. This test increases the possibility of a defendant being acquitted of a crime by reason of insanity. However, that state also enacted a regressive statute authorizing the commitment of a person found not guilty of a crime

Criminal insane classified.-(I)(a) The following classes of patients shall be designated as patients to be confined in said criminal ward:

(b) Dangerous persons who have committed or shall attempt to commit murder, arson, rape, robbery or other high crimes or misdemeanors;

(c) Those charged with committing any of the crimes before mentioned who are believed to feign insanity or of whose insanity there may be so great a doubt as to require the investigation of examiners;

(d) Those acquitted of such crimes on the ground of insanity, who shall be adjudged by the court trying the offense as dangerous persons to be at large;

(e) Those charged with the commission of any of such crimes and becoming insane before trial or sentence;

(f) Those becoming insane while in prison after conviction of any crime, and continuing insane throughout the term of sentence who shall not have friends or relatives to whom such persons may be delivered at the expiration of sentence;

(g) Insane convicts generally whose insanity shall have been ascertained and

who may be transferred in accordance with section 71-2-4.

18 For a discussion of the legality and desirability of statutes in one jurisdiction governing the confinement of mentally ill non-criminal criminals, see G. Morris, The . Confusion of Confinement Syndrome Extended: The Treatment of Mentally Ill "NonCriminal Criminals" in New York, 18 BuFF. L. REv. 392 (1969).

19 Smith, Psychiatry in Corrections, 120 AM. J. PsYchratry 1045 (1964); see also Wille, Psychiatric Facilities in Prisons and Correctional Institutions in the United States, 114 AM. J. Psychiatry 481 (1957).

20 State v. Jones, 50 N.H. 369 (1871).

21 Durham v. United States, 214 F.2d 862 (D.C. Cir. 1954). 
by reason of insanity to either the state hospital or the state prison..$^{22}$ That statute is still in effect today. ${ }^{23}$

But I choose not to confine my thoughts to the prisons and the overwhelming inadequacy of diagnosis and treatment of mental illness within those institutions. Let me direct my attention to other arrangements designed to dispose of the problem of criminality and mental illness. At least 32 states have established maximum security wards within their state hospitals or penal institutions in which various categories of mentally ill criminals and/or non-criminal criminals are confined. ${ }^{24}$ Ten states, primarily the larger, and allegedly more progressive, have built separate institutions for these patients. ${ }^{25}$ While these institutions often have long and impressive-sounding titles, they are commonly known by the name of the town in which they are located. Atascadero ${ }^{26}$ and Vacaville ${ }^{27}$ in California, Menard ${ }^{28}$ in Illinois, Patuxent $^{29}$ in Maryland, Bridgewater ${ }^{30}$ in Massachusetts, Ionia ${ }^{31}$ in Michigan, Dannemora $^{32}$ and Matteawan ${ }^{33}$ in New York, Lima ${ }^{34}$ in Ohio, and

22 N.H. REv. Stat. ANN. § 607:3 (Supp. 1967).

23 A Vermont statute contains a similar provision. Vr. STAT. ANN. tit. 13, $\$ 4805$ (1958). 24 S. RUBIN, supra note 12 , at 517-8.

25 Id. at 518.

26 CAL. WelF. \& INST. Code § 7200 (Deering Supp. 1968) (Atasacadero State Hospital). For a description of treatment at Atasacadero State Hospital, see The Mentally Ill Offender (unpublished, undated pamphlet written by the patients of Atascadero State Hospital); Comment, California's Sexual Psychopath-Criminal or Patient? I U. SAN FRAN. L. REv. 332 (1967).

27 CAL. PEN. Code $\S \S 6100-7$ (Deering 1959) (Medical Facility). For a description of treatment at the Medical Facility, see Ernst \& Keating, Psychiatric Treatment of the California Felon, 120 Am. J. Psychiatry 974 (1964).

28 Ill. AnN. Stat. ch. 911/2, \& 100-14 (1966) (mllinois Security Hospital). For a description of treatment at the Illinois Security Hospital, see N. Morris, Psychiatry and the Dangerous Criminal, 41 S. CAL. L. REv. 514, 522-3 n.25 (1968).

29 MD. ANN. CoDE art. $31 \mathrm{~B}$, §§ 1-4 (1957) (Patuxent Institution).

30 Mass. ANN. LAws ch. 123, § 22A (Supp. 1968) (Bridgewater State Hospital). For a description of treatment at Bridgewater State Hospital, see CommonweALTH OF MASSAchusetts, Governor's Committee to Study the MassachusetTs Correctional System, SECOND REPORT 47 (1956), in Goldstein \& Katz, Abolish the "Insanity Defense"-Why Not?, 72 Yale L.J. 853, 870 n.48 (1963); Boston Herald, Feb. 27, 1967, at 8, col. 1.

31 Mrch. STAT. ANN. \$§ 14.854-9 (1956, Supp. 1969) (Ionia State Hospital). For a description of treatment at Ionia State Hospital, see Hess \& Thomas, Incompetency to Stand Trial: Procedures, Results, and Problems, 119 AM. J. Psychratry 713 (1963).

32 N.Y. CoRrec. LAW §§ 375-90 (McKinney 1968) (Dannemora State Hospital). For a description of treatment at Dannemora State Hospital, see G. Morris, The Confusion of Confinement Syndrome: An Analysis of the Confinement of Mentally Ill Criminals and Ex-Criminals by the Department of Correction of the State of New York, 17 BuFF. L. REv. 651 (1968).

33 N.Y. CoRrEc. LAw §§ 400-15 (McKinney 1968) (Matteawan State Hospital). For a description of treatment at Matteawan State Hospital, see Morris, supra note 32, at 654-9.

34 OHTO REv. CoDE $\$ \S 5125.01, .03, .06-13$ (1968) (Lima State Hospital- $\$ 5125.03$; State Hospital for Criminal Insane and Psychopathic- \$\$ 5125.06-.13). 
Farview ${ }^{35}$ in Pennsylvania, are but a partial listing. These institutions can be regarded as the ultimate in the segregation process, i.e., the mentally ill_-"good" sick people-are isolated from the mentally ill criminals and non-criminal criminals__bad" sick people. While some of these institutions were constructed in the 1800's, it cannot be concluded that they are remnants of an outmoded treatment philosophy. The California institutions were erected in the 1950's and Massachusetts is currently considering constructing a multi-million dollar replacement of its facility at Bridgewater. ${ }^{36}$

By definition, the maximum security institution deprives its patients of an essential treatment opportunity, to wit, the open door. The open door means more than freedom of movement from one ward to another. The open door permits access to modern therapies such as trial release, convalescent care, out-patient clinics, and community services. The closed doors of a maximum security ward lock out these therapies.

What is the effect of the closed door on the mental patient's potential for recovery from his illness and release from the institution? Let me compare the average length of confinement of patients in a maximum security institution with the average length of confinement of patients in the regular (civil) mental hospitals in the same state. ${ }^{37}$ Matteawan is a maximum security institution in New York State. According to the statistics released by the Superintendent of that institution, ${ }^{38}$ there were 1,654 patients in Matteawan in August 1965. Seven hundred ninety-six had been confined there prior to 1958. The median stay in Matteawan was therefore a minimum of six to seven years. ${ }^{39}$ This must be compared with the four month average length of hospitalization in the civil hospitals. ${ }^{40}$ Equally alarming is the number of patients who have been subjected to inordinately prolonged confinement at Matteawan:

35 PA. STat. ANN. tit. 50, § 1140(b) (Supp. 1969) (Farview State Hospitai). For a description of treatment at Farview State Hospital, see Note, Hospitalization of Mentally Ill Criminals in Pennsylvania and New Jersey, 110 U. PA. L. REv. 78 (1961).

36 The Boston Sunday Herald, Oct. 23, 1966, § 4, at 3, col. 5, reported that preliminary layouts and blueprints for a new facility call for construction of a \$12.5 million state hospital as the first phase.

37 See generally, Morris, supra note 32 , at 656-7.

38 Letter and accompanying data from W.C. Johnston, M.D., to Grant H. Morris, November $22,1966$.

39 The median of 1,654 is 827 . Since 796 patients were hospitalized in Matteawan before 1958, and 858 during or after 1958, the median confinement period lies between six and seven years. It should be noted that this is a minimum confinement period since some of the 1,654 patients continued to be confined after August 1965 for varying lengths of time.

40 N.Y. State Dep't of Mental Hyglene, State Programs for the Mentaley Ill and MENTALly Retarded 4 (1965). 
703 patients were incarcerated in 1955 or earlier-a minimum of ten years;

306 patients were incarcerated in 1945 or earlier-a minimum of twenty years;

119 patients were incarcerated in 1935 or earlier-a minimum of thirty years;

29 patients were incarcerated in 1925 or earlier-a minimum of forty years;

4 patients were incarcerated in 1915 or earlier-a minimum of fifty years. ${ }^{41}$

According to the August 1965 figures, the patient longest in residence at Matteawan was committed there in 1901-a total of sixty-four years. ${ }^{42}$

While civil hospital patients are released into the community, Matteawan patients generally are not so released. They are returned to courts for trial, returned to penal institutions, or are transferred to civil hospitals. One would expect under these circumstances that doctors at Matteawan would be more willing to release patients, and that, as a consequence, patient movement from Matteawan would be more fluid than from the civil hospitals. The opposite is clearly true. I can only conclude that the effect of the closed door, the effect of maximum security, the effect of custodial orientation is devastating.

\section{II}

But is there some valid social policy which justifies the disparity in treatment opportunity? The obvious answer is that mentally ill criminals and mentally ill non-criminal criminals as a class are more dangerous than ordinary mental patients. Of necessity, they must be more securely confined.

I reject this simplistic explanation and will attempt to show the fallacy of its premise. To do so, I must acquaint the reader with another category of mental patient, a Supreme Court decision, and an administrative response to that decision. Suppose a convict becomes mentally ill while serving his sentence in prison. If he is confined in a

41 Letter and accompanying data from W.C. Johnston, M.D., to Grant T. Morris, November 22, 1966.

42 Dr. Johnston's statistics classify this patient in a preconviction category. The person had been indicted of a crime, found mentally incapable of standing trial, and committed to Matteawan. According to the Bar Association of the City of New York, he was committed to Matteawan when he was 19 years old and continued to be confined at that maximum security institution beyond his 83rd birthday. Association OF THE BAR OF THE City of New York, Mental Illness, Due Process and the Criminal Defendant $72-73$ (1968). 
New York State prison, he will be transferred to Dannemora State Hospital, a maximum security institution adjoining Clinton Prison and administered by the Department of Correction. ${ }^{43}$ Upon expiration of his sentence he is no longer a mentally ill convict; he is a mentally ill ex-convict. When he acquires that status is he to be treated as an ordinary civil mental patient in a Department of Mental Hygiene hospital, or as a mentally ill, non-criminal criminal in a Department of Correction maximum security institution? A New York State statute provided that upon expiration of sentence, the mentally ill ex-convict was committed to the custody of the Commissioner of Mental Hygiene to be placed in an appropriate institution in the Department of Mental Hygiene or the Department of Correction. ${ }^{44}$ Obviously, placement in a maximum security Department of Correction institution was "appropriate" only if the ex-convict was dangerous and in need of maximum security confinement. Johnnie $\mathrm{K}$. Baxstrom was a mentally ill convict who had been transferred from prison to Dannemora during his sentence. Upon expiration of that sentence, and in accordance with the statute, the Commissioner of Mental Hygiene designated Dannemora as the appropriate institution for the continued confinement of the patient. Baxstrom brought a writ of habeas corpus. The Supreme Court of the United States held ${ }^{45}$ that Baxstrom had been denied equal protection of the laws in contravention of the fourteenth amendment of the Constitution. Chief Justice Warren wrote the opinion for eight members of the Court and Mr. Justice Black concurred in the result. The Court reasoned that although commitment pursuant to the statute was deemed a civil commitment, ${ }^{46}$ the statutory procedure, in authorizing the Commissioner of Mental Hygiene administratively to determine civil commitability, denied Baxstrom the possibility of a jury review of this question which was available to all other persons civilly committed in New York. ${ }^{47}$ Additionally the statute, in authorizing the Commissioner of Mental Hygiene to order Baxstrom confined in an institution maintained by the Department of Correction, deprived Baxstrom of a judicial hearing to determine whether he was dangerously mentally ill. Under New York law a civil patient could not be transferred from a civil hospital to a Department of Correction maximum security mental institution unless he was first judicially deter-

\footnotetext{
43 N.Y. CoRREC. LAw § 383 (McKinney 1968).

44 N.X. Laws ch. 540, $\$ 4$ (1965) (repealed 1966). Prior to its repeal by N.Y. Laws ch. 891 , § 1 (1966), the statute was codified as N.Y. Correc. LAw $\S 384$.

45 Baxtrom v. Herold, 383 U.S. 107 (1966).

46 N.Y. Laws ch. 540, \& 4 (1965) (repealed 1966).

47 N.Y. MENT. HYG. LAW \$ 74 (McKinney Supp. 1968) as renumbered and amended by N.Y. Laws ch. 738, § 6 (1964).
} 
mined to be dangerously mentally ill. ${ }^{48}$ The statute unconstitutionally circumvented this procedural safeguard in the case of Baxstrom and other ex-convict mental patients.

The Baxstrom decision did not result in the immediate discharge of a single patient from Dannemora directly into society. Rather, the Department of Mental Hygiene "transferred" to civil state hospitals all ex-prisoners whose sentences had expired and who were being held at Dannemora pursuant to the unconstitutional statute. This process was denominated "Operation Baxstrom."49

In order to accomplish this "transfer" it was necessary to have these patients admitted as involuntary civil patients. The Superintendent of Dannemora petitioned for the admission of each patient to a civil state hospital, stating that in his opinion "this man is mentally ill and requires further care and treatment in a civil state mental institution." Involuntary civil commitment requires the examination of two physicians prior to the admission of the patient to a civil hospital. Physicians on the staff of Dannemora State Hospital were utilized for these examinations. While the transfer of 425 patients from Dannemora was directly attributable to the unconstitutionality of the statute, ${ }^{50}$ additional classes of patients at Matteawan, who were similarly situated, were also transferred. ${ }^{51}$ Nearly a thousand patients were chopped from the roles of Dannemora and Matteawan by the Baxstrom axe. ${ }^{52}$

How did the Operation Baxstrom patients fare upon transfer into the civil state hospitals? In analyzing the data reluctantly released ${ }^{53}$

48 N.Y. Ment. Hyg. LAW § 85 (McKinney Supp. 1968). There is a similar provision for dangerously mentally defective patients. N.Y. MENT. HyG. LAW \& 135 (McKinney Supp. 1968).

49 Johnnie K. Baxstrom himself, was transferred to Marcy State Hospital pursuant to Operation Baxstrom. He requested a review and a rehearing of the order of retention, and a jury found him not mentally ill. The New York Supreme Court, County of Oneida, Judge Mead presiding, ordered his release and discharge on May 24, 1966. The Utica Observer Dispatch, June 8,1966 , at 25, reported that Baxtrom died of an epileptic seizure on June 7, 1966.

50 Letter from R.E. Herold, M.D., to Grant H. Morris, December 30, 1966.

51 See e.g., N.X. Laws ch. 879, § 1 (1965); N.Y. Correc. LAw § 412, repealed by N.Y. Laws ch. 524, § 1 (1965).

$52 \mathrm{~A}$ letter and accompanying data from C. Stamatovich, M.D., Assistant Commissioner of Mental Hygiene to Grant H. Morris, December 21, 1966, listed 992 Operation Baxstrom patients. Interestingly, the Department of Mental Hygiene has used the figure of 969 patients in its analysis of Operation Baxstrom. Hunt \& Wiley, Operation Baxstrom After One Year, 124 AM. J. PsychiatRy 974 (1968). A version of that article also appeared in Association OF THE BAR OF THE CTTY OF NEW YoRK, supra note 42, at 221-8.

53 Letter and accompanying data from C. Stamatovich, M.D., to Grant H. Morris, December 21, 1966. The letter began:

"Merry Christmasl

After checking with Mr. Weinstein (Statistics) the decision is that you may have this 
by the Department of Mental Hygiene, it must be remembered that all of the patients transferred into the civil state hospitals had previously been administratively determined by the Department of Mental Hygiene to be too dangerously mentally ill to be in the civil hospitals. Although the Supreme Court in Baxstrom ruled that procedurally, judicial hearings were necessary for the confinement of a dangerous civil patient in a Department of Correction institution, supposedly the experts, the psychiatrists in the Department of Mental Hygiene, had administratively designated Dannemora and Matteawan as the "appropriate institutions" 54 for confinement of these ex-convicts only after a determination in each individual case that the patient to be retained there was in fact dangerously mentally ill.

The Department of Mental Hygiene compiled data for a threemonth period (March, 1966 to May, 1966) ${ }^{\mathbf{5 5}}$ and a six-month period (March 1, 1966 to August 31, 1966). ${ }^{56}$

The three-month statistics listed 865 patients admitted to the civil state hospitals pursuant to Operation Baxstrom. Within the threemonth period, 173 patients were retained as "voluntary" patients. A voluntary patient is one who may discharge himself from the hospital by giving 10 days written notice of his intention or desire to leave. ${ }^{.7}$ There had been a change to the legal status of "informal" patient in an additional 18 cases. An informal patient is one who is free to leave the hospital at any time. ${ }^{58} \mathrm{~A}$ total of 182 patients had freedom of the grounds. While 25 patients were discharged within the period, only four of the 865 were retransferred as dangerously mentally ill to maximum security confinement at Matteawan.59

\footnotetext{
information-if you promise to let us see how you intend to use it (censoring?)" However, it should be noted that Operation Baxstrom information has become available to to the public. Hunt \& Wiley, supra note 52.

54 See, e.g., N.Y. Laws ch. 540 \$ 4 (1965) (repealed 1966) (Dannemora). Ironically, N.Y. Laws ch. 879, § 1 (1965) authorized retention at Matteawan of prisoners (misdemeanants and female felons) upon expiration of their terms of imprisonment without specifically requiring even an administrative determination of dangerous mental illness. However, the Commissioner of Mental Hygiene was authorized to transfer sentence-expired civil patients to civil state hospitals and presumably would have done so if in fact they were administratively determined to be not dangerous.

55 Robert C. Hunt, M.D., Assistant Commissioner, N.Y. State Dep't of Mental Hygiene, Memo. No. 4, June 24, 1966.

56 "Report on Baxstrom Cases for Period of March 1, 1966 to August 31, 1966" in letter and accompanying data from C. Stamatovich, M.D., to Grant H. Morris, December 21, 1966.

57 N.Y. MENT. HYG. LAW § 71(1) (McKinney Supp. 1968). Note however, that a proceeding to convert the patient to an involuntary status may be undertaken during the 10 day notice period.

58 N.Y. MENT. HYG. LAw \& 71 (2) (McKinney Supp. 1968).

69 The Counsel of the Department of Mental Hygiene has described the retransfer provision as a "simple procedure." D. WILEY, Review of MENTAL HyGIENe AND RELATED LEGISLATION FOR THE YEAR 196513 (1965).
} 
Thus the statistics revealed that the number of patients released absolutely to the community in the first three months of Operation Baxstrom was six times greater than the number returned to Department of Correction confinement as dangerously mentally ill. Even more startling was the fact that within the initial period, less than one half of one per cent of the patients were found to be so dangerously mentally ill that they required retransfer to Matteawan-even though prior to Operation Baxstrom, supposedly they all were dangerous.

The six-month statistics continued, and in fact, emphasized the trend. The number of patients transferred from maximum security confinement pursuant to Operation Baxstrom increased from 865 to 992. Of the 992 cases reported, 273 had been converted to a voluntary status and 24 had become informal patients. Twenty-two were conditionally released from the civil hospitals on convalescent care ${ }^{60}$ and an additional 42 left the hospitals on other statuses. ${ }^{61}$

For the full six-month period, 79 patients were discharged while only six of the 992 were retransferred to Matteawan as dangerously mentally ill. Thus the number of Baxstrom patients unconditionally released to the community was 13 times greater than the number of patients who found their way back to Department of Correction mental confinement. A miniscule six-tenths of one per cent of the Baxstrom patients were actually too dangerous to be treated in the civil state hospitals.

After one year, the Department of Mental Hygiene reported:

[T]he most striking news is that there is no news. None of the hospitals has any particular problems to report. The hospital directors all use similar terms in conveying that the Baxstrom patients are no more problem than anyone else, that nobody any longer thinks of them in any special way, that no lists are kept and that one never hears any reference to this group by staff or patients. ${ }^{2}$

After one year, 147 Baxstrom patients had been discharged to the community as compared with seven patients who were recommitted to Matteawan as dangerously mentally ill. ${ }^{63}$ For each patient retransferred from the civil hospitals, 21 were absolutely discharged.

60 Pursuant to N.Y. MENT. HYG. LAW § 87(1)(d) (McKinney Supp. 1968).

61 The 42 patients were listed as being in the following categories: family care, escape, leave without consent, and leave. The number of patients in each category was not given, however.

62 Hunt \&: Wiley, supra note 52, in Association of THE BAR of the CITY OF NEW YoRK, supra note 42 , at 224 .

63 Id. at 225 . 
There are three conclusions that can be drawn from the Operation Baxstrom successes. First, the psychiatrists in the Department of Mental Hygiene lacked the ability properly to diagnose dangerous mental illness and to determine the necessity for maximum security confinement. Only seven of the 992 patients diagnosed as dangerously mentally ill prior to the Supreme Court decision in Baxstrom were in fact dangerous. Second, before the Supreme Court required the removal of ex-convict mental patients from maximum security confinement, the Department of Mental Hygiene was unwilling to accept and treat mental patients whose lives had been stained by the label of criminality. ${ }^{64}$ And third, the Department of Mental Hygiene did have the ability-in terms of personnel and facilities-to treat over 99 per cent of the patients that it considered dangerously mentally ill. When these ex-convict patients were integrated with other civil patients and given treatment indistinguishable from that afforded other civil patients, they responded readily. ${ }^{65}$

\section{III}

These observations, though based on the New York experience with mentally ill ex-convicts, are applicable to all states that classify mental patients utilizing the irrevelant factor of "criminality" and impose maximum security confinement on all patients so classified. The assumption that all mentally ill criminals and mentally ill non-criminal criminals are dangerous is unfounded. The myth must be destroyed. The core of my position concerns mentally ill sentence-serving convicts and I will concentrate on that category. When a prisoner becomes physically ill, his illness is treated within the prison itself. For example, a prisoner with a toothache is adequately treated by a dentist within the prison, and his confinement at that institution is not interrupted. However, the unique nature of serious mental illness requires interruption

64 White, Krumholz \& Fink, The Adjustment of Criminally Insane Patients to a Civil Mental Hospital, 53 MENT. Hyg. 34 (1969). In discussing the transfer of Dannemora patients to Central Islip State Hospital (a civil state hospital) the authors concluded: "Superficially it appears that, somehow, a sum was taken of two negative labels, 'criminal' plus 'psychotic,' that yielded a supernegative value of 'the psychotic criminal.' These two labels derive from two different philosophies of human behavior and are perhaps complementary approaches to the same phenomenon. In any case, they do not have additive properties." Id. at 38.

65 Although all Operation Baxstrom patients were transferred into the civil hospitals as involuntary patients, $36 \%$ of the patients remaining in the civil hospitals on August 31, 1966 were retained on a voluntary or informal status. This compares favorably with the $39 \%$ of civil patients generally that were admitted from the community in June 1966 on these noncompulsory statuses. N.Y. State Dep't of Mental Hygiene, Monthly Statistical Report for June 19663 (1966). 
of a prisoner's confinement and transfer to a mental hospital or psychiatric ward for treatment of that illness. Under this circumstance, is there any valid basis for distinguishing between the treatment accorded him and the treatment accorded other mentally ill individuals who are hospitalized for their illnesses? The distinction can only be claimed as permissible due to the convict's status as a "criminal." However, proper treatment for mental illness depends not on any status such as "criminal," but on considerations of the diagnosis and pathology of the individual's illness.

When a defendant is found guilty of a crime, he is not usually sentenced to a maximum security mental institution or a maximum security hospital ward. His incarceration begins in prison. If he becomes so mentally ill that he must be transferred out of the prison for purposes of treatment, why should he be disadvantaged in that treatment by the requirement of maximum security confinement? Why doesn't society say that due to a change in mental condition, he is no longer the person he was at the time he committed the crime, and, until his mental illness subsides, is no longer a fit subject for punishment? His criminal status should dissolve, albeit temporarily, and he should be treated like any other mental patient. A possible need for security safeguards to be undertaken by the treating hospital does not logically depend on a "criminal" label that preceded the patient's mental illness.

It is obvious that many mentally ill persons are convicted of crimes daily. It may be assumed that in some instances the commission of a criminal act is a manifestation of underlying mental illness existing at the time of the act. Mental illness in convicts does not necessarily "develop" after confinement in prison. But even such an analysis does not support the existing requirement of maximum security confinement for all mentally ill convicts. A criminal may be regarded as a person who is too dangerous to live in society due to his commission of an anti-social act. For this reason society requires his confinement in prison. But when the sentence-serving criminal is transferred out of the prison for purposes of treatment, the question of "dangerousness" becomes relevant only in relation to the environment to which he is to be sent, i.e., the mental hospital, not the community. If a man's only crime is larceny, one need not fear if he is placed in a hospital where personal property of any intrinsic value is confiscated from patients at the time of admission. Without adequate Boy Scout training in the rubbing of sticks together, one need not fear an arsonist in a matchless place. Similarly, one need not fear a rapist in a sexually segregated institution. The question of "whether" a person is dangerous to the 
mental hospital in which he is confined is not disposed of by an analysis of "when" his mental illness developed.

A non-convict who becomes sufficiently mentally ill may be committed to a mental hospital because he is too dangerous to live in society. Whether security measures will be imposed on a civil mental patient is determined by the inability of the patient to comprehend and respect the rights of other patients, hospital staff, and the community should he escape. These considerations, which depend upon the pathology and severity of the particular illness, are the only rational considerations and should be applied to "criminal" mental patients as well.

It has never been determined that sentence-serving convicts suffer from different mental illnesses from persons who are civilly committed. ${ }^{60}$ Absent such a finding, mentally ill convicts who are transferred out of the prison environment for treatment of their mental conditions are similarly situated with all other persons who have been removed from society and confined for treatment of their mental conditions. Since criminal status is irrevelant to the capability to treat, it should be irrevelant to the right to treatment. Mentally ill convicts are entitled to treatment equal to that received by civilly-committed patients. Whether one compares the statistics on average length of confinement or the relative stigma attaching from confinement, ${ }^{67}$ the inescapable conclusion is that "segregated" treatment of any class of mental patient in a maximum security facility is inherently unequal, ${ }^{68}$ inherently discriminatory, and inherently unjust. ${ }^{69}$

In advocating equality of treatment for all classes of mental patients, I have concentrated on the lack of treatment opportunities offered mentally ill criminals and non-criminal criminals. But to complete the picture, I should mention one extra "treatment opportunity" that some mentally ill criminals and non-criminal criminals are receiving due to their status. They are subjected to human experimentation where ordinary mental patients are not so subjected.

For example, in any large mental hospital there exists a small number of individuals who continue their aggressive, acting-out behavior

66 See S. RuBIN, supra note 12, at 520-1.

67 When necessary, courts, in comparing institutions have examined those qualities which are incapable of objective measurement. See Sweat v. Painter, 339 U.S. 629 (1950) (comparison of law schools).

68 See Brown v. Board of Education, 347 U.S. 483, 495 (1954) ("Separate educational facilities are inherently unequal.").

69 Maximum security confinement of convict mental patients when such security is neither needed nor therapeutically desirable may also constitute cruel and unusual punishment. See the discussion of Robinson v. California, 370 U.S. 660 (1962) in Morris, supra note 32 , at $662-3$. 
during their hospitalization. To curb this unacceptable behavior, the usual hospital procedure is to transfer the acting-out patient to a ward for the acutely disturbed, medicate him, and if necessary, place him in restraint until the acute stage is past. ${ }^{70}$ In seeking a potential substitute for this procedure, California has recently experimented with the drug succinylcholine chloride sold under a trade name of Anectine. Hereafter I will refer to the drug by that trade name. Anectine was injected intravenously to produce respiratory arrest. The patients' intercostal muscles and diaphragms were affected and a period of apnea was produced. For a period of one and one-half to two minutes of muscle paralysis, the patients, though fully conscious, were not able to breathe. During this one and one-half to two minute interval, male technicians made oral statements to the patients, suggesting that they improve their behavior in the future. ${ }^{71}$ The human guinea pigs for these experiments were the mentally ill criminals and non-criminal criminals confined in California's maximum security institutions at Vacaville and Atascadero. The Vacaville study utilized 64 patients; ${ }^{72}$ the Atascadero study utilized 90 patients. ${ }^{73}$ The Vacaville researchers interviewed 35 recipients of the drug, ${ }^{74}$ and their report contained the following observations: "How severe is the Anectine experience from the point of view of the patient? Sixteen likened the experience to dying. Three of these compared it to actual experiences in the past in which they had almost drowned. The majority described it as a terrible, scary experience."7s

The reports of these experiments reminded me of the statement of Dr. Karl Menninger in his most recent book: "Once upon a time, we must admit, we doctors with the best of intentions did treat some patients with torture. That, thank God, was long ago." ${ }^{.76}$ His expression of thankfulness was premature.

Any aversive treatment may be questionable. The Anectine experiments are an extreme example of aversive treatment. But however startling is the fact that these experiments were conducted at all, even more shocking is the admission that some patients utilized in the treatments did not consent in any way to the experimental "therapy." One

70 Reimringer, Morgan \& Bramwell, Succinylcholine as a Modifier of Acting-Out Behavior I (unpublished, undated article from Atascadero State Hospital).

71 Id. at 1-2. Mattocks \& Jew, Assessment of an Aversive Treatment Program with Extreme Acting-Out Patients in a Psychiatric Facility for Criminal Offenders 5-6 (unpublished, undated article from the California Medical Facility).

72 Mattocks \& Jew, supra note 71 , at 7.

73 Reimringer, Morgan \& Bramwell, supra note 70, at 2.

74 Mattocks \& Jew, supra note 71, at 9.

$75 \mathrm{Id}$. at 15 .

78 K. MENNINGER, supra note 9 , at 253. 
report contained these statements: "A few subjects were given the Anectine treatment following the occurence of an episode of aggressive acting-out without prior warning that they would receive such a treatment. Others were told in advance that if, and only if, they did certain acts would they be given a treatment, emphasizing that through control of their own behavior they could avoid receiving an Anectine injection." "77 "On five patients, consent was not received from the patient himself, but was granted by the institution's Special Treatment Board. Thus these five patients were included in the treatment program against their will."78

As disclosed by these reports, the experiments were conducted in apparent violation of the Nuremburg Code, ${ }^{79}$ the Declaration of Helsinki, ${ }^{80}$ the American Medical Association Ethical Guidelines for Clinical Investigation, ${ }^{81}$ and Food and Drug Administration regulations. ${ }^{82}$

The problem of obtaining informed consent for treatment of, or experimentation on, any confined mental patient remains largely uninvestigated. The need for such exploration is particularly acute in the case of the patient who has also been afflicted with criminality.

77 Mattocks \& Jew, supra note 71, at 2-3.

$78 I d$. at 5 .

79 U.S. Adjutant General's Dep'T, Trials of War Griminals Before Nuremberg Milltary Tribunals Under Control Council Law No. 10, The Medical Case, vol. 2, 181-3 (1947). (The voluntary consent of the human subject is absolutely essential. The experiment should be so conducted as to avoid all unnecessary physical and mental suffering and injury.)

80 See 190 J.A.M.A. 195 (1964). The Declaration of Helsinki recommended, among other things, that if at all possible, consistent with patient psychology, the doctor should obtain the patient's freely given consent after the patient has given a full explanation. In case of legal incapacity, consent should also be procured from the legal guardian. The Declaration of Helsinki is composed of a list of recommendations guiding doctors in clinical research. It was adopted by the World Medical Association in 1964. Id.

81 The Ethical Guidelines for Clinical Investigation which were adopted by the House of Delegates, American Medical Association, November 30, 1966, see 198 J.A.M.A. 1158 (1966), provide that in clinical investigation primarily for treatment, voluntary consent must be obtained from the patient, or from his legally authorized representative if the patient lacks the capacity to consent, following: (a) disclosure that the physician intends to use an investigational drug or experimental procedure, (b) a reasonable explanation of the nature of the drug or procedure to be used, risks to be expected and, possible therapeutic benefits, (c) an offer to answer any inquiries concerning the drug or procedure, and (d) a disclosure of alternative drugs or procedures that may be available.

82 2I C.F.R. § 130.37 (1968) (consent for use of investigational new drugs on humans; statement of policy). 2I G.F.R. $\$ 130.37(\mathrm{~h})$ (1968) provides: " 'Consent' means that the person involved has legal capacity to give consent, is so situated as to be able to exercise free power of choice, and is provided with a fair explanation of pertinent information concerning the investigational drug, and/or his possible use as a control, as to enable him to make a decision on his willingness to receive said investigational drug." 
Finally, in proposing equal treatment for mentally ill criminals and non-criminal criminals, I am aware of the new problems and new questions that are posed. If a mentally ill criminal is considered to be a civil patient in all respects, does he have a right to be released from the hospital on convalescent care? If so, should a mentally ill sentenceserving convict be released to the community or returned to prison? If the fact of institutionalization in a prison was the precipitating cause of a convict's mental illness, would not returning him to that same institutional environment $t^{83}$ be psychiatrically harmful? If it was the fact of institutional life, in and of itself, that initially caused a convict's mental illness, should he be transferred from one institution (prison) to another (mental hospital) or should he be treated solely on an outpatient basis? Does prison life cause mental illness in a substantial number of prisoners? If so, should such confinement be eliminated as cruel punishment regardless of conviction of crime? Should society be required to seek alternatives to confinement in prison for some, if not all, prisoners? If institutional life causes or aggravates mental illness, then should society be required to seek alternatives to institutionalization of any mental patient?

While these questions present obvious difficulties, I submit that they should not deter an attempt to institute the basic solution. Using as a guideline the goal of adequate and equal treatment of all mental patients irrespective of other status, decisions can be made to implement a rational treatment plan.

No longer can society ignore the problem of the artificially disadvantaged mental patient. No longer can society avoid attacking the problem by relying on eminent psychiatrists who state, "[O]ur psychiatric hospitals are not psychologically prepared at the present time to be assigned the task of detaining and treating patients who have been labeled prisoners." 84

83 See, e.g., N.Y. CoRREC. LAW $\$ \$ 386,410$ (McKinney 1968) which provide that whenever any person who was confined in Dannemora ( $\$ 386)$ or Matteawan $(\S 410$ ) as a mentally ill person has recovered prior to the expiration of his sentence, he shall be transferred to the institution from which he came and the person in charge of such institution "shall in all respects, treat him as when originally sentenced to imprisonment." $84 \mathrm{~K}$. MENNINGER, supra note 9, at 263. 